\title{
ENHANCING INNOVATION IN THE E-MOBILITY SECTOR USING PRE-COMMERCIAL PROCUREMENT - THE HYDROGEN STORAGE PROGRAMME*
}

DATA PRZESŁANIA: 30.09.2018, DATA AKCEPTACJI: 20.12.2018, KOD JEL: H57

\section{Krzysztof Matan, Katarzyna Ziółkowska, Nina Zys}

\author{
University of Warsaw \\ krzysztof.matan@ncbr.gov.pl \\ k.ziolkowska@wpia.uw.edu.pl \\ nina.zys $œ$ ncbr.gov.pl
}

\begin{abstract}
On 17th of May 2018, the National Centre for Research and Development has announced the initiation of a new public procedure within the Hydrogen Storage Programme. The direct objective of the Programme is to develop an innovative and safe Hydrogen Storage System (HSS) intended for use with fuel cells in mobile facilities in order to create an effective alternative for fossil fuels in the transport sector. The Programme should end with the demonstration of the method's operation in the Mobile Facility (such as bus, boat, drone, trolley, forklift, locomotive, etc.). The competition procedure based on pre-commercial procurement has been chosen as the most effective organizational approach towards the Programme. The structure of the programme assumes the application of a new method of financing research based on the "problem-driven research" model developed by the US agency DARPA.

This article contains a concise analysis of the methods used by the National Centre for Research and Development to procure solutions in the area of hydrogen storage technology (in line with the concept of "the State as an intelligent clienl").

KEYWORDS pre-commercial procurement, hydrogen storage, innovations, the National Centre for Research and Development, DARPA
\end{abstract}

\section{INTRODUCTION}

On a European level, one of the main documents setting out the overall strategy and the objectives of the post-crisis EU market is "Europe 2020. A strategy for smart, sustainable and inclusive

* All contents contained in this publication are an expression of the personal views of the authors and do not reflect the views and opinions of the National Centre for Research and Development. 
growth" (European Commission [EC], 2010). The new economic governance presented therein emphasizes, among others, the importance of target public funding and wider use of green technologies, resulting in supporting innovation incentives by public sector procurement.

Within the national context, the basic document containing a comprehensive description of the political directions for the economic development is "Strategy for Responsible Development" adopted by the Council of Ministers in 2017 (Council of Ministers, 2017). With regard to the initiatives for modern industry, it indicates the growing importance of solutions based on electricity supply i.a. for public or passenger transportation. The Strategy specifies that in order to achieve the goals set therein, public institutions should be obliged to cooperate closely with entrepreneurs, the scientific community and the society in general.

One of such public institution is the National Centre for Research and Development. As the executive agency of the Minister of Science and Higher Education, NCRD was established, pursuant to art. 1 of the Act on the National Centre for Research and Development (Act, 2010), to carry out tasks concerning science, technology and innovation policy of the State, especially by providing financial support for scientific, technological and innovative R\&D projects. Importantly, it is intended to support the implementation of the above mentioned EU and national economic development plans.

Acting in accordance with directives defined at the EU and national level in order to encourage innovation in the economy, NCRD created the "Hydrogen storage" Programme. Pursuant to the clause 1.1. 1) of the Programme's Regulations, the direct factor initiating the preparation of the Programme was the assumption that the NCRD will implement a new method of financing research based on the "problem-driven research" model, in the area of hydrogen storage technology. This new formula of the Programme assumes resigning from the model of research funding which is typical in Poland so far (i.e. by awarding grants for individual projects), and rather focusing on creating a comprehensive research program containing a portfolio of projects. Each of them is intended to contribute to the program's main objective - to solve the problem or to meet the specific needs of particular recipient by developing a technological solution that is not available on the market at the given time.

\section{ABOUT THE PROGRAMME}

The commencement of the proper procurement procedure was preceded by the determination of the technological problem, i.e. the need to develop a hydrogen storage for mobile applications (fuel cell power supply, generating electricity in an environmentally safe way). It has been noted that such a solution could become an effective alternative to ion-lithium batteries. The entire procedure is aimed at enhancing development of the electromobility in Poland. By using hydrogen storage technology, mobile vehicles could be charged faster without overloading the electricity grids. Particular attention was also drawn to the possibility of the clean hydrogen production (without emitting air pollutions, using for instance renewable energy sources). Before selecting contractors, the NCRD conducted also a technical dialogue in order to obtain from the representatives of the energy as well as transportation sector, the necessary information on hydrogen storage in general and the most innovative technological solutions in this field. Relevant adjustments of the Pro- 
gramme's documentation (in particular within the available budget and schedule) was therefore possible thanks to received information on the actual capacity of potential contractors and their expectations as to the essential contractual terms.

In the scope of organization of research and development works, the competition proceedings have been divided into three stages:

1. Stage I (duration 60 days) will focus on the creation and development of the concept of the final solution. This stage is to be addressed to a wide range of contractors.

2. Stage II (duration 365 days) will start after verifying the technical potential of the selected contractors and includes carrying out research and development works completed with the development of the initial prototype.

3. Stage III (duration: 600 days) will take place after verifying the commercial capabilities of the contractors and will involve the development of the entire method documentation and the creation of the final prototype which is to be ready to demonstrate its operation in the mobile facility.

The number of contractors after each stage will be limited on the basis of the verification of their work results so far and the assessment of the potential to participate in further stages. As part of each subsequent stage, the amount of financial means intended for the payment of remuneration to the contractors will also increase.

The program is financed by the European Regional Development Fund as part of the project lead by the NCRD as a Beneficiary, named "Raising the level of innovativeness of the economy through the implementation of a new model of financing breakthrough research projects", implemented under sub-measure 4.1.3 Innovative management methods for the Intelligent Development Operational Programme 2014-2020, in accordance with the co-financing agreement of April 12, 2017, no. 00-0001/16. NCRD intends to allocate over 30 million PLN for the financing of the research and development work. In its basic assumptions the Programme should be closed by 2021 (NCRD, 2018a; NCRD, 2018b).

\section{"PROBLEM-DRIVEN RESEARCH"APPROACH}

Identification of the problem and finding its potential solutions is the essence of the innovative approach of the National Centre for Research and Development to the research in the transportation sector.

Within the framework of the "Hydrogen storage" Programme, NCRD has been deriving from and developing experience concerning "problem driven research" model, gained by the NCRD team in other programs such as "Emission-free Public Transport (E-Mobility)" and "Blocks 200+".

Following that approach of establishing the programmes with their objectives, planned outputs and procedures, considerable emphasis has to be given to the development of innovations and searching for alternative ways of running the programme rather than using the traditional methods of financing R\&D works. The new formula implies, therefore, resignation from the assigning of grants to individual projects. Instead of that, comprehensive research programs are created and they consist of a portfolio of projects whose contractors compete with each other, so as to obtain the most cost-effective and technologically optimal solution (method or product). 
In this way, thanks to the precise definition of the problem to be solved and cooperation with stakeholders as to the potential solutions, the State is not only a dispatcher of funds for research and development, but takes on the role of an intelligent client.

The solution used by NCRD is modeled on the financing scheme for R\&D works, developed by one of the research agencies in the US - the Defense Advanced Research Projects Agency. DARPA, using this model, has revolutionized the approach to managing $\mathrm{R} \& \mathrm{D}$. It is crucial that the subject of the research programs is always a direct response to the specific needs of the State. Additionally, the results of R\&D works can be later used both commercially and by administrative institutions, thus stimulating the demand for innovation by the public sector. In the DARPA method, its focus on implementation is probably the most visible - the success of a single project means that it changes realities in a given field. Strategic thinking in order to achieve this change is an integral part of every project.

The professionalism of project managers and the flexible process of management enables dynamic response to the risk of failure. Program managers have the ability to quickly redirect or cut off projects in the event that certain milestones are not met. The program as a whole is considered a failure only if it fails due to lack of due diligence, clearly defined measures and objectives or due risk reduction. This definition allows focusing on sector-specific, high-risk, potentially profitable projects aimed at achieving breakthrough solutions (Matan, Ziółkowska, 2018, p. 269).

\section{PRE-COMMERCIAL PROCUREMENT AS AN INSTRUMENT TO PROMOTE INNOVATION}

Introduction and spread of information on the pre-commercial procurement by the European Commission has been hailed by the doctrine as providing the public administration with a powerful measure that will allow it to order products and services that were previously unobtainable and that can help face crucial social challenges in case of market failure (Polish Agency for Enterprise Development, 2012, pp. 9-10). The normative basis of the procedure is fixed in the Communication from the Commission - Pre-commercial Procurement: driving innovation to ensure sustainable high quality public services in Europe (European Commission, 2007).

Pre-commercial procurement (also referred to as the PCP) relates to the purchase of the results of research and development works by the public sector. The basis for commencement of the PCP procedure is the recognition of the need to solve a significant socio-economic problem or an important challenge, the solution of which is not possible by means of products or solutions already existing on the market. It should be emphasized, however, that the procedure under PCP necessarily ends at the stage of developing full documentation and/or prototypes and a narrow batch of products - that is the implementation of previously undertaken research and development works. In this respect, the difference between this mode and the innovation partnership is clearly visible. Although both procedures are aimed at supporting innovation and obtaining a product or solution that does not exist on the market, the pre-commercial procurement does not include the commercialization phase. As a result, only a solution (method) is to be created. The implementation of that solution for the mass production is not carried out within the framework of the pre-commercial procurement procedure. This has specific consequences as to the legal possibilities and restrictions regarding the shape of the procedure. 
The term pre-commercial procurement is not defined anywhere in the national law. However, the Public Procurement Law (2004) excludes it from its scope of application. According to art. 4 point 3 letter e) of the PPL, ${ }^{1}$ the provisions of the Public Procurement Law do not apply to contracts whose subject is "research and development services, unless they are covered by codes CPV from 73000000-2 to 73120000-9, 73300000-5, 73420000-2 and 73430000-5 [...] and if all the following conditions are met: the benefits of these services are gained exclusively for the contracting authority for its own business, the entire remuneration for the service provided is paid by the contracting authority". Therefore, the provisions of the PPL do not apply to pre-commercial procurement as providing for the distribution of benefits between the contracting authority and the contractor.

Detailed standards relating to the pre-commercial procurement procedure are set out in the Commission Communication - Framework for State aid for research, development and innovation (European Commission, 2014). According to part 2.3. point 33 of the Framework Rules, awarding a contract for conducting research and development services under the pre-commercial procurement formula does not constitute state aid within the meaning of art. 107 of the Treaty on the Functioning of the European Union, if the price paid for research and development services fully reflects the market value of the benefits obtained by the contracting authority and the risk incurred by the participating service providers. The European Commission indicates that it is necessary to prepare the procurement under an open, transparent, non-discriminatory procedure in which the selection of contractors is made on the basis of objective selection criteria, while the benefits in the area of intellectual property rights are shared between the contracting authority and the contractor. In this way, both parties have also an incentive to pursue wide commercialization and take up innovative solutions.

Doctrine indicates several important features of PCP procedure that make it an innovation policy measure:

1. Gearing towards very specific goals in a focused way - the procurement addresses directly relevant public need (especially when implemented together with "problem-driven research" model).

2. Unbundling of R\&D and production - the focus is on technological aspects, pre-commercial procurement gives an opportunity to acquire research and development works, which may later lead to innovative solutions that will outperform those already available on the market, but the contract itself is not affected by the current demand.

3. Benefits from IP are shared between the contracting authority and the contractor.

4. Competitive development in stages - multiple private firms and/or scientific units compete to carry out an exploratory phase and propose suitable solutions to the defined technological problem.

5. Risk sharing - the public institutions fund the R\&D works, but the pre-commercial phase gives them possibility of full-scale commercialization of the elaborated solution.

6. Multiple sourcing - it is possible that as a result of the procurement several solutions will be prepared unlike a traditional procurement where single sourcing is typical (Iossa, Biagi, Valbonesi, 2018, pp. 10-12).

1 Introduced into the Public Procurement Law by virtue of the implementation of Article 14 of Directive 2014/24/ EU into the domestic legal order. 


\section{CONCLUSIONS}

The potential of innovative public procurement has been emphasized in a number of EU reports (e.g. European Commission, 2015). Member States were obliged to set aside dedicated budgets for public procurement of innovative products and services as well as pre-commercial procurement. Specific resources for procurement of innovation have been devoted in the EU Framework Programme for Research and Innovation ("Horizion 2020") (European Commission, 2011).

Pre-Commercial Procurement challenges industry from the demand side to develop innovative solutions for public sector needs, as well as stimulates private companies to carry out industrial research on their own; or to cooperate with scientific units in order to develop new solutions. The Authors believe that these were the key features of the procedure that has determined the shape of the "Hydrogen Storage" Programme as PCP. Research and development works focused on the methods of hydrogen storage and its use to fuel cells are an opportunity for a new stage in the development of environmentally friendly technologies. The solutions developed in the future within the framework of this Programme may be used, among others, in emission-free modes of transport, as mobile sources of electric power, or in technologies used for storing electric energy from RES.

What's more, the "Hydrogen Storage" program is a natural consequence of the NCRD's activities already undertaken in the broadly understood area of electromobility support. It is therefore an another initiative, consistent with the aforementioned "Emission-free Public Transport" Program and the announced launch of a program dedicated to the creation of infrastructure for charging zero emission vehicles.

In this context NCRD appears as an intelligent contracting party, but at the same time an active creator of innovation. Using customized procedure of PCP and "problem-driven research" method, it has created a realistic possibility to acquire a breakthrough solution for hydrogen storage and electromobility in general.

\section{REFERENCES}

Act 30.04.2010 on the National Centre for Research and Development. Official Journal 2018, item 1249, as amended.

Council of Ministers (2017). Resolution No. 8 of the Council of Ministers of February 14, 2017 on adopting the Strategy for Responsible Development until 2020 (with a perspective until 2030). M.P. 2017, item 260.

European Commission (2007). Communication from the Commission to the European Parliament, the Council, the European Economic and Social Committee and the Committee of the Regions - Pre-commercial Procurement: driving innovation to ensure sustainable high quality public services in Europe. COM(2007) 799.

European Commission (2010). Communication from the Commission, EUROPE 2020. A strategy for smart, sustainable and inclusive growth. $\operatorname{COM}(2010) 2020$.

European Commission (2011). Communication from the Commission to the European Parliament, the Council, the European Economic and Social Committee and the Committee of the Regions, Horizon 2020 - The Framework Programme for Research and Innovation. COM/2011/0808.

European Commission (2014). Communication from the Commission - Framework for State aid for research, development and innovation. Official Journal of the European Union 2014/C 198/01.

European Commission (2015). Public Procurement for Research and Innovation. Retrieved from: http://ec.europa.eu/invest-in-research/pdf/download_en/edited_report_18112005_on_public_procurement_for_research_and_innovation. pdf (26.09.2018). 
Iossa, E., Biagi, F., Valbonesi, P. (2018). Pre-commercial Procurement, Procurement of Innovative Solutions and Innovation Partnerships in the EU: Rationale and Strategy. Econornics of Innovation and New Technology, 8 (27), 730-749. DOI: 10.1080/10438599.2017.1402431.

Matan, K., Ziólkowska, K. (2018). The Acquisition of Innovative Methods of Modernization for Power Units Using Pre-Commercial Procurement. Scientific Papers of the Institute of Mineral Resources Management of the Polish Academy of Science, 102, 261-276.

National Centre for Research and Development (2018). Announcement of Initiation of Public Procedure Case No. 113/18/ PU of May 17, 2018. Retrieved from: https://www.ncbr.gov.pl/index.php?id=32359\&L=0\%252523a6_ul\&tx_news_ pil\%5Bnews\%5D=47889\&cHash=e915e3c49616f044e83acb495a8a79a2 (26.09.2018).

National Centre for Research and Development (2018). Regulations for Conducting a Competition Procedure under the Name: "Hydrogen Storage". Retrieved from: https:/www.ncbr.gov.pl/fileadmin/user_upload/akutalnosci/pl/6211/h2 storage_pl_en_regulations_www.pdf (26.09.2018).

Polish Agency for Enterprise Development (2012). Innovative and Pre-Commercial Public Orders. Retrieved from: https:// www.uzp.gov.pl/_data/assets/pdf_file/0020/30683/Innowacyjne_i_przedkomercyjne_zamowienia_publiczne_2012. $\operatorname{pdf}(26.09 .2018)$.

Public Procurement Law of 29.01.2004. Official Journal 2017, item 1579, as amended.

Treaty on the Functioning of the European Union. Official Journal 2012/C 326/01.

\section{WSPIERANIE INNOWACJI W OBSZARZE ELEKTROMOBILNOŚCI PRZY UŻYCIU PROCEDURY ZAMÓWIEŃ PRZEDKOMERCYJNYCH - PROGRAM MAGAZYNOWANIA WODORU}

STRESZCZENIE

SKOWA KLUCZOWE
W dniu 17 maja 2018 r. Narodowe Centrum Badań i Rozwoju ogłosiło rozpoczęcie nowej publicznej procedury w ramach Programu Magazynowania Wodoru. Bezpośrednim celem programu jest opracowanie innowacyjnego i bezpiecznego Systemu Zasobnika Wodoru (SZW) z przeznaczeniem do zasilania ogniw paliwowych w obiektach mobilnych $w$ celu stworzenia alternatywy dla paliw kopalnych w sektorze transportu. Program ma zakończyć demonstracja opracowanej metody w Obiekcie Mobilnym (takim jak autobus, łódź, dron, wózek widłowy, lokomotywa itp.). Procedura konkursowa oparta na modelu zamówień przedkomercyjnych została wybrana jako najefektywniejszy sposób organizacji programu. Struktura programu zakłada także zastosowanie nowej metody finansowania badań na podstawie modelu problem driven research, rozwijanego przez amerykańską agencję DARPA.

Niniejszy artykuł stanowi zwięzłą analizę metod wykorzystywanych przez Narodowe Centrum Badań i Rozwoju dla pozyskania rozwiązań z zakresu magazynowania wodoru (zgodnie $z$ koncepcją „Państwo jako inteligentny zamawiający”).

zamówienia przedkomercyjne, magazynowanie wodoru, innowacje, Narodowe Centrum Badań i Rozwoju, DARPA 